\title{
DESIGN IN ISO 9001:2015
}

\author{
Radosław WOLNIAK \\ Silesian University of Technology, Department of Organization and Management, Institute of Economy and \\ Informatics; rwolniak@polsl.pl, ORCID: 0000-0003-0317-9811
}

Purpose: The aim of the paper is to analyse the problems connected with the design of operation processes realised within an organisation in the ISO 9001:2015 implementation process.

Design/methodology/approach: Critical literature analysis. Analysis of international literature from main databases and Polish literature and legal acts connecting with the researched topic.

Findings: Design and development planning refers to identifying the stages and controls for the stages to design and develop products. Stages that are appropriate for product development are decided by a design team. An organisation is required to plan and develop its design and development activities as a process. The goal of this process is to ensure that the realisation of the product or service will be according to their specification. The design and development processes, operations, activities and controls shall be planned in accordance to several requirements. The organisation should implement the planned arrangements at appropriate stages to verify that the product and service requirements have been met. The release of products and services to the customer shall not proceed until the planned arrangements have been satisfactory completed, unless otherwise approved by a relevant authority and as applicable by the customer.

Originality/value: Detailed analysis of all subjects related to the organisation of design in ISO 9001:2015.

Keywords: quality management, ISO 9001:2015, ISO 9001, operations, design.

Category of the paper: literature review.

\section{Introduction}

Quality management systems are very broadly widespread in today's organisations. World, European and Polish firms implement quality management system according to ISO 9000 series requirements (ISO 9001:2015, Chen et al., 2016; Cholewicka-Goździk, 2016; Łagowski and Żuchowski, 2016; Wolniak and Hąbek, 2015; Wolniak and Skonicka-Zasadzień, 2010; Wolniak and Sułkowski, 2015; Wolniak, 2020). From time to time there is a new edition of the ISO 9001 standard, and organisations should rearrange its management system according to its 
requirement (Hillson, 2001; Gębczyńska and Wolniak, 2018; Juszczak-Wiśniewska and Ligarski, 2015, 2016; Łuczak and Wolniak, 2016; Sułkowski and Wolniak, 2016, 2018; Szczucka-Lasota and Wolniak, 2018). The newest version of the quality management standard which can be implemented in organisations is from 2015 and is called ISO 9001:2015 Quality management systems - Requirements. The standard describes the basic requirements that organisations need to implement (Horodecka and Wolniak, 2015; Pacana, 2014; Pacana et al., 2014, 2017; Pacana and Stadnicka, 2006, 2017; Wolniak, 2011; Wolniak and Sułkowski, 2015, 2016; Wolniak et al., 2019; Wolniak and Skotnicka-Zasadzień, 2008, 2011, 2019).

Design and development planning refers to identifying the stages and controls for the stages to design and develop products. Stages that are appropriate for product development are decided by a design team (Natarajan, 2017). The organisation is required to plan and develop its design and development activities as a process (Kaoru, 1988; Pokińska et al., 2002; Robins and Coulter, 2006; Szkiel, 2016). The goal of this process is to ensure that the realisation of the product or service will be according to their specification. The design and development processes, operations, activities and controls shall be planned in accordance with several requirements (Hoyle, 2009; Ząbek, 2016; Żemigła, 2017; Salvendy, 2001).

The aim of the paper is to analyse the problems connected with the design of control processes realised within an organisation in the ISO 9001:2015 implementation process.

\section{Typical design plan}

For each process stage, the organisation must determine (Figure 1) (Abuhav, 2017):

- its relevant activities;

- the associated resources (internal as well as external);

- the associated controls and actions for addressing risks;

- the necessary development tools;

- the necessary monitoring and measuring devices:

- its verification and validation activities,

- its responsibilities and authorities,

- the need for involvement of customers and users. 
Design inputs

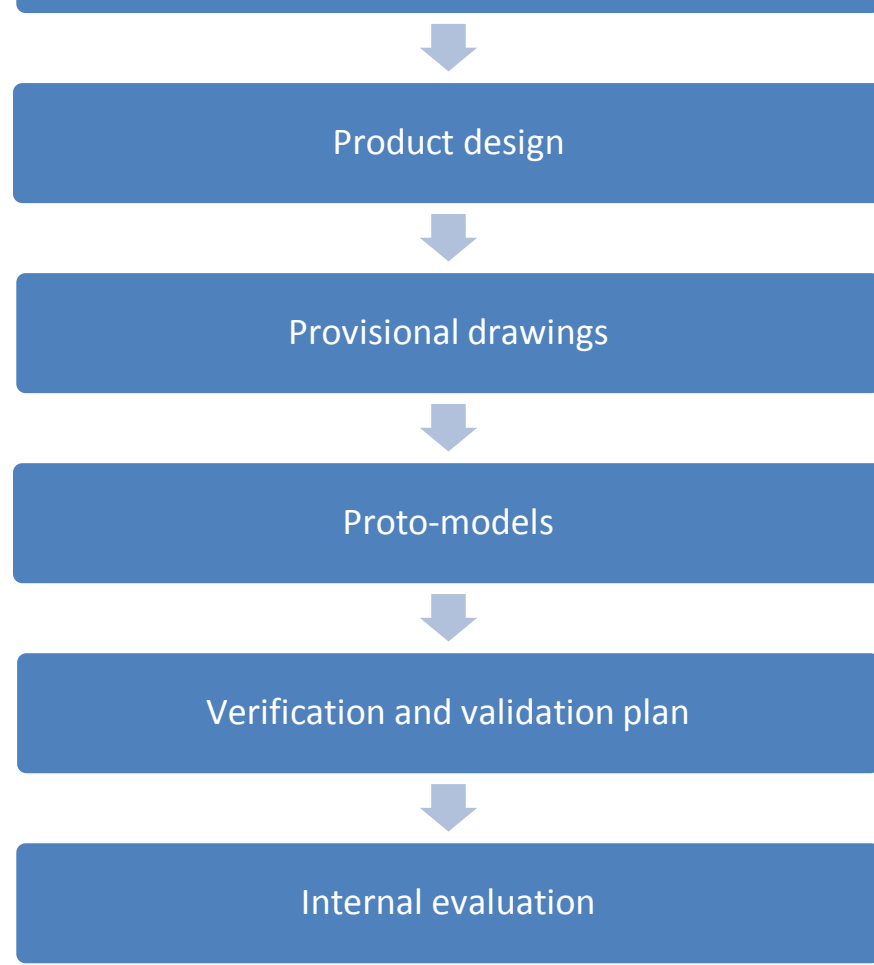

Test infrastructure for production

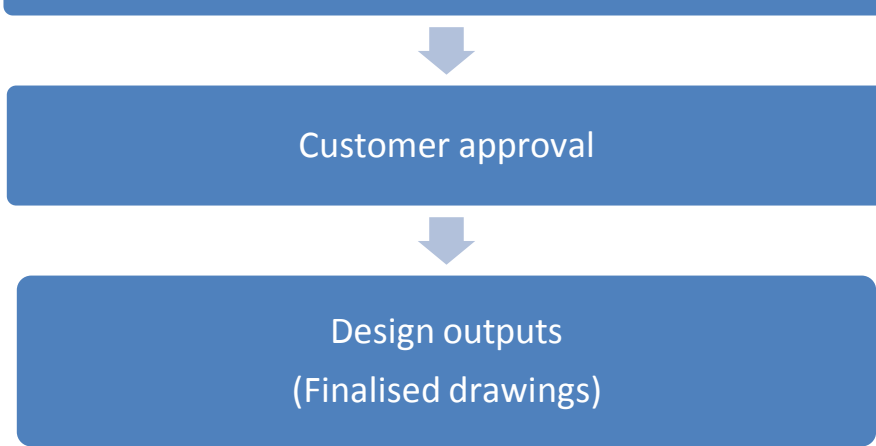

Figure 1. Typical design and development plan. Source: (Natarajan, 2017).

Examples of process stages include the following (Abuhav, 2017):

- Marketing reviews.

- Concept and planning.

- Research.

- Prototype design.

- Development realisation process.

- Development of realisation controls.

- Test of batch manufacturing.

- Changes and modifications.

- Launching the product. 
- Control after launch.

- Updates and modifications.

The design and development processes of products and services in ISO 9001:2015 are presented in Table 1.

Table 1.

Design and development of products and services in ISO 9001:2015

\begin{tabular}{|c|c|}
\hline Requirement & Characteristic \\
\hline $\begin{array}{c}\text { Design and } \\
\text { development planning }\end{array}$ & $\begin{array}{l}\text { - the nature, duration and complexity of the design and development activities; } \\
\text { - the required process stages, including applicable design and development } \\
\text { reviews; } \\
\text { - the required design and development verification and validation activities; } \\
\text { - the responsibilities and authorities involved in the design and development } \\
\text { process; } \\
\text { the internal and external resource needs for the design and development of } \\
\text { products and services; } \\
\text { the need to control interfaces between persons involved in the design and } \\
\text { development process; } \\
\text { - } \text { the need for involvement of customers and users in the design and development } \\
\text { process; } \\
\text { the requirements for subsequent provision of products and services; } \\
\text { the level of control expected for the design and development process by } \\
\text { customers and other relevant interested parties; } \\
\text { the documented information needed to demonstrate that design and } \\
\text { development requirements have been met. }\end{array}$ \\
\hline $\begin{array}{r}\text { Desig } \\
\text { developm }\end{array}$ & $\begin{array}{l}\text { - } \quad \text { functional and performance requirements; } \\
\text { - information derived from previous similar design and development activities; } \\
\text { - } \quad \text { statutory and regulatory requirements } \\
\text { - } \quad \text { standards or codes of practice that the organisation has committed to } \\
\text { implement; } \\
\text { - } \quad \text { potential consequences of failure due to the nature of the products and services. }\end{array}$ \\
\hline $\begin{array}{c}\text { Design and } \\
\text { development controls }\end{array}$ & $\begin{array}{l}\text { - the results to be achieved are defined; } \\
\text { reviews are conducted to evaluate the ability of the results of design and } \\
\text { development to meet requirements; } \\
\text { verification activities are conducted to ensure that the design and development } \\
\text { outputs meet the input requirements; } \\
\text { validation activities are conducted to ensure that the resulting products and } \\
\text { services meet the requirements for the specified application or intended use; } \\
\text { any necessary actions are taken on problems determined during the reviews, or } \\
\text { verification and validation activities; } \\
\text { - documented information of these activities is retained. }\end{array}$ \\
\hline $\begin{array}{c}\text { Design and } \\
\text { development outputs }\end{array}$ & $\begin{array}{l}\text { - meet the input requirements; } \\
\text { are adequate for the subsequent processes for the provision of products and } \\
\text { services; } \\
\text { include or reference monitoring and measuring requirements, as appropriate, } \\
\text { and acceptance criteria; } \\
\text { specify the characteristics of the products and services that are essential for } \\
\text { their intended purpose and their safe and proper provision. }\end{array}$ \\
\hline $\begin{array}{c}\text { Design and } \\
\text { development changes }\end{array}$ & $\begin{array}{l}\text { - design and development changes; } \\
\text { - the results of reviews; } \\
\text { - the authorisation of the changes; } \\
\text { - the actions taken to prevent adverse impact }\end{array}$ \\
\hline
\end{tabular}

Source: Own work on the basis of (ISO 9001:2015). 


\section{Control of design}

Organisations should ensure that externally provided processes, products and services conform to requirements (Wolniak, 2013, 2014, 2016, 2017, 2019; Wolniak and SkotnickaZasadzień, 2014; Ścierski, 2011). The control should be applied to externally provided processes, products and services when (ISO 9001:2015):

- products and services from external providers are intended for incorporation into the organisation's own products and services;

- products and services are provided directly to the customer(s) by external providers on behalf of the organisation;

- a process, or part of a process, is provided by an external provider as a result of a decision by the organisation.

Organisations should determine and apply criteria for the evaluation, selection, monitoring of performance and re-evaluation of external providers, based on their ability to provide processes or products and services in accordance with the requirements (Ligarski, 2013, 2014; Stramatis, 1995; Locher, 2008; Mitra, 2016; Montgomery, 2009; Purushothama, 2015). Organisations should retain any documented information of these activities and any necessary actions arising from the evaluations (Novakova et al., 2016; Olkiewicz et al., 2019). The basic requirements of ISO 9001:2015 standards connected with control are presented in Table 2 . The main problem of the quality management system is related to production and service provision. The main requirements connected to this kind activity are shown in Table 3.

Table 2.

Control in ISO 9001:2015

\begin{tabular}{|c|c|c|}
\hline Requirement & \multicolumn{1}{c|}{ Characteristic } \\
\hline & $\begin{array}{l}\text { ensure that externally provided processes remain within the control of its quality } \\
\text { management system; }\end{array}$ \\
$\begin{array}{c}\text { Type and } \\
\text { extent of } \\
\text { control }\end{array}$ & $\begin{array}{l}\text { define both the controls that it intends to apply to an external provider and those it intends } \\
\text { to apply to the resulting output; } \\
\text { take into consideration: }\end{array}$ \\
& $\begin{array}{l}\text { - the potential impact of the externally provided processes, products and services on the } \\
\text { organisation's ability to consistently meet customer and applicable statutory and } \\
\text { regulatory requirements } \\
\text { the effectiveness of the controls applied by the external provider; }\end{array}$ \\
& $\begin{array}{l}\text { determine the verification, or other activities, necessary to ensure that the externally } \\
\text { provided processes, products and services meet requirements. }\end{array}$ \\
\hline
\end{tabular}


Cont. table 2.

\begin{tabular}{|c|c|}
\hline $\begin{array}{c}\text { Information } \\
\text { for external } \\
\text { providers }\end{array}$ & 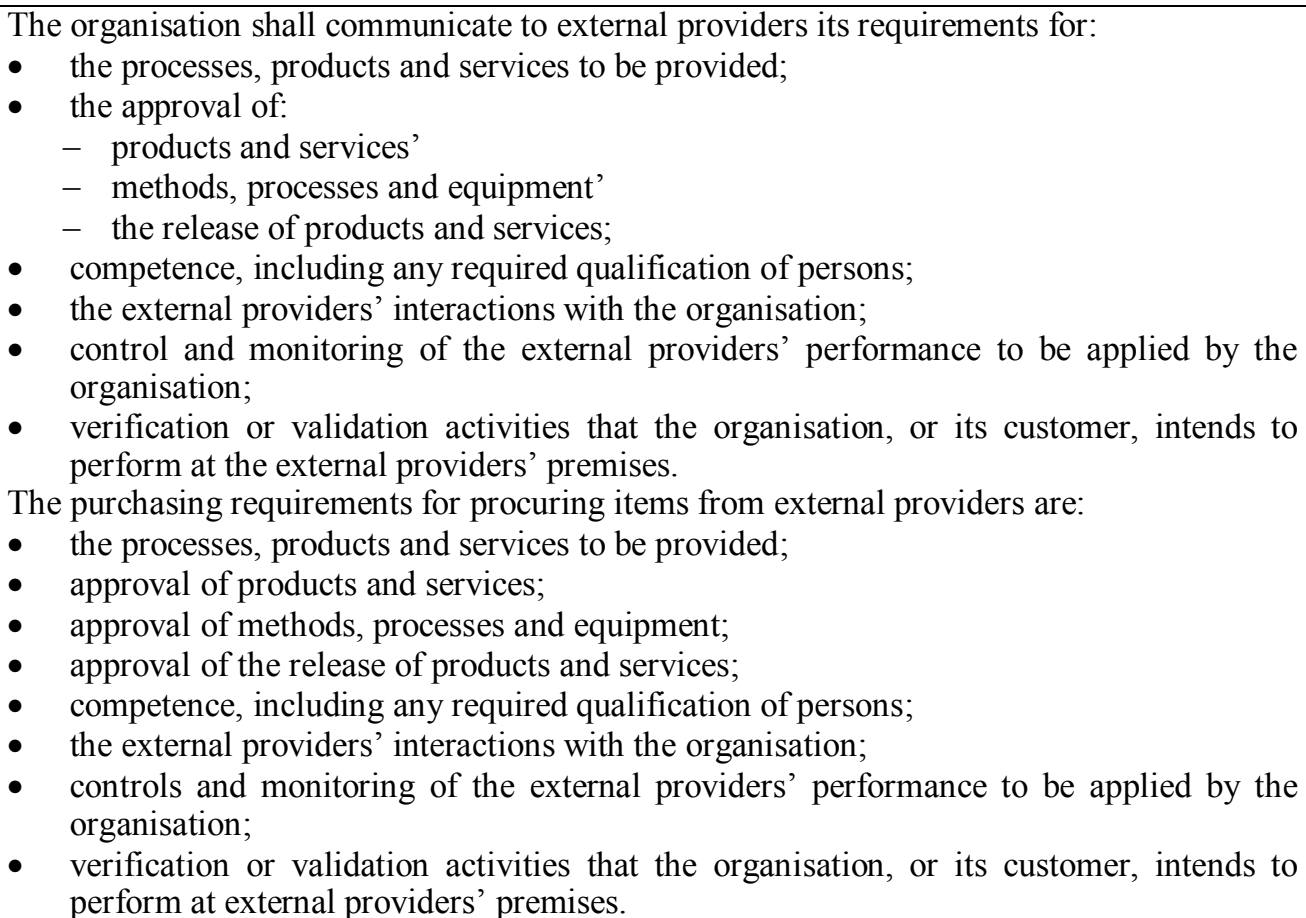 \\
\hline $\begin{array}{l}\text { Information } \\
\text { for external } \\
\text { providers }\end{array}$ & $\begin{array}{l}\text { The organisation is required to ensure with a method that all the necessary information } \\
\text { regarding the purchased product is identified prior to their communication with the } \\
\text { external provider. The goals are to: } \\
\text { - ensure that all the requirements regarding the purchase are identified, including } \\
\text { approval of the requirements and definition of controls; } \\
\text { develop the ability to transfer to one's supplier clear specifications regarding the } \\
\text { product; } \\
\text { - ensure that the supplier receives all the information it needs in order to verify its } \\
\text { ability to deliver the products or services according to the requirements; } \\
\text { - ensure that all the required information is received from the supplier. } \\
\text { The organisation shall ensure the adequacy, quality and clarity of specified requirements } \\
\text { of purchased products or services prior to their communication to the external provider. } \\
\text { - The organisation shall communicate to the external provider the requirements of the } \\
\text { services or the products, including important information. The information shall include } \\
\text { the description of the products and services to be provided or the processes or activities } \\
\text { to be performed. } \\
\text { The information shall include requirements for approval and release activities necessary } \\
\text { to ensure that externally provided processes, products, and services will be delivered as } \\
\text { expected. } \\
\text { - The information shall refer to methods, processes, procedures, and the use of tools and } \\
\text { equipment needed for the realisation of purchased products or services. } \\
\text { The information shall include necessary release activities -- activities for the verification } \\
\text { that all requirements were met. } \\
\text { The information shall include competence, training and qualification requirements } \\
\text { relevant to the realization of the purchased products and services. } \\
\text { The information shall describe the methods and content of the interactions between the } \\
\text { organisation and the external provider. } \\
\text { The organisation shall determine and implement activities and controls and monitor the } \\
\text { performance of the external providers. } \\
\text { The organisation shall determine the verification or validation activities that the } \\
\text { organisation or its customer intends to perform at the external providers' premises. }\end{array}$ \\
\hline
\end{tabular}

Source: Own work on the basis of (ISO 9001:2015; Nartarajan, 2017; Abuhav, 2017). 
Table 3.

Production and service provision in ISO 9001:2015

\begin{tabular}{|c|c|}
\hline Requirement & Characteristic \\
\hline $\begin{array}{c}\text { Control of } \\
\text { production } \\
\text { and service } \\
\text { provision }\end{array}$ & $\begin{array}{l}\text { Controlled conditions shall include, as applicable: } \\
\text { - the availability of documented information that defines: } \\
\text { - the characteristics of the products to be produced, the services to be provided or the } \\
\text { activities to be performed, } \\
\text { - the results to be achieved; } \\
\text { - the availability and use of suitable monitoring and measuring resources; } \\
\text { the implementation of monitoring and measurement activities at appropriate stages to } \\
\text { verify that criteria for control of processes or outputs and acceptance criteria for products } \\
\text { and services, } \\
\text { - the use of suitable infrastructure and environment for the operation of processes; } \\
\text { - the appointment of competent persons, including any required qualification; } \\
\text { the validation, and periodic revalidation, of the ability to achieve planned results of the } \\
\text { processes for production and service provision, where the resulting output cannot be } \\
\text { verified by subsequent monitoring or measurement; } \\
\text { the implementation of actions to prevent human error. }\end{array}$ \\
\hline $\begin{array}{c}\text { Identification } \\
\text { and } \\
\text { traceability }\end{array}$ & $\begin{array}{l}\text { - The organisation shall use suitable means to identify outputs when it is necessary to } \\
\text { ensure the conformity of products and services. } \\
\text { - The organisation shall identify the status of outputs with respect to monitoring and } \\
\text { measurement requirements throughout production and service provision. } \\
\text { - The organisation shall control the unique identification of the outputs when traceability } \\
\text { is a requirement, and shall retain the documented information necessary to enable } \\
\text { traceability. }\end{array}$ \\
\hline $\begin{array}{l}\text { Property } \\
\text { belonging to } \\
\text { customers or } \\
\text { external } \\
\text { providers }\end{array}$ & $\begin{array}{l}\text { - The organisation shall exercise care with property belonging to customers or external } \\
\text { providers while it is under the organisation's control or being used by the organisation. } \\
\text { - The organisation shall identify, verify, protect and safeguard customers' or external } \\
\text { providers' property provided for use or incorporation into the products and services. } \\
\text { When the property of a customer or external provider is lost, damaged or otherwise found } \\
\text { to be unsuitable for use, the organisation shall report this to the customer or external } \\
\text { provider and retain documented information on what has occurred. }\end{array}$ \\
\hline Preservation & $\begin{array}{l}\text { The organisation shall preserve the outputs during production and service provision, to the } \\
\text { extent necessary to ensure conformity to requirements. } \\
\text { Preservation includes the provisions for handling semi-finished products from one process to } \\
\text { next process. A few examples are provided for understanding the needs for the preservation } \\
\text { of products: } \\
\text { - Adhesives should be preserved at recommended ambient conditions. } \\
\text { - Chemicals should be preserved considering safety provisions. } \\
\text { - Electronic components should be preserved to prevent electro-static damages. The same } \\
\text { precautions should be considered while issuing partial quantities. } \\
\text { - Coaxial cables should be preserved in spools to retain impedance characteristics. } \\
\text { - The same precautions should be considered while issuing partial quantities. } \\
\text { disposed or returned to manufacturers. }\end{array}$ \\
\hline
\end{tabular}


Cont. table 3.

\begin{tabular}{|c|c|}
\hline $\begin{array}{c}\text { Post-delivery } \\
\text { activities }\end{array}$ & $\begin{array}{l}\text { In determining the extent of post-delivery activities that are required, the organisation shall } \\
\text { consider: } \\
\text { - } \quad \text { statutory and regulatory requirements; } \\
\text { - } \text { the potential undesired consequences associated with its products and services; } \\
\text { - } \text { the nature, use and intended lifetime of its products and services; } \\
\text { customer requirements; } \\
\text { customer feedback. } \\
\text { In determining the extent of implementing post-delivery activities for products and services, } \\
\text { the organisation shall consider: } \\
\text { - Statutory and regulatory requirements: The statutory and regulatory requirements are } \\
\text { adhered to when implementing post-delivery activities. Directives for managing } \\
\text { electronic wastes, procedures for the safety certifications of lifts and regulations for } \\
\text { wearing personal protective equipment are examples of statutory and regulatory } \\
\text { requirements for implementing post-delivery activities. } \\
\text { Potential undesired consequences: Customer dissatisfaction is generally one of the } \\
\text { critical undesired consequences and is considered in planning the extent of post-delivery } \\
\text { activities. After-sales influence the relationship to the extent that customers will switch } \\
\text { to competitors and, furthermore, influence the reputation of the company. The cost of } \\
\text { providing post-delivery activities should also be considered, as an organisation might } \\
\text { have constraints. } \\
\text { Nature, use and intended lifetime: The nature, use and intended lifetime of products are } \\
\text { considered for planning the extent of post-delivery activities. For example, the lifetime } \\
\text { of consumer products is less than that of military products, and hence the availability of } \\
\text { spare parts is planned accordingly. } \\
\text { Extent of customer requirements: For example, customers of consumer products expect } \\
\text { prompt service at reasonable costs, especially for the out-of-warranty period. Hence, a } \\
\text { wider service network is planned compared to military products. } \\
\text { Customer feedback: Customer feedback is used for improving the performance of } \\
\text { products and services to customers. The extent of obtaining customer feedback is } \\
\text { indicated in the quality procedure for customer satisfaction. }\end{array}$ \\
\hline $\begin{array}{l}\text { Control of } \\
\text { changes }\end{array}$ & $\begin{array}{l}\text { - The organisation shall review and control changes for production or service provision, to } \\
\text { the extent necessary to ensure continuing conformity with requirements. } \\
\text { The organisation shall retain documented information describing the results of the review } \\
\text { of changes, the person(s) authorising the change and any necessary actions arising from } \\
\text { the review. }\end{array}$ \\
\hline
\end{tabular}

Source: Own work on the basis of (ISO 9001:2015; Nartarajan, 2017; Abuhav, 2017; Natarajan, 2015; Misztal, 2013; Vogt, 2010; Egonsson et al., 2013).

\section{Conclusion}

Organisations should implement the planned arrangement at appropriate stages to verify that the requirements of the products and services have been met. The release of products and services to the customer shall not proceed until the planned arrangements have been satisfactory completed, unless otherwise approved by a relevant authority and as applicable to the customer. Organisations should retain documented information on the release of products and services. The documented information should include: ${ }^{1}$

- evidence of conformity with the acceptance criteria;

- traceability to the person(s) authorising the release.

\footnotetext{
${ }^{1}$ ISO 9001:2015. Quality management systems - Requirements.
} 


\section{References}

1. Abuhav, I. (2017). ISO 9001:2015. A Complete Guide to Quality Management Systems, London: CRC Press.

2. Chen, C.K., Lee, J.D., Dahlgaard, J.J. (2016). A stepwise ISO-based TQM implementation approach using ISO 9001:2015. Management and Production Engineering Review, 4, 65-75.

3. Cholewicka-Goździk, K. (2016). Struktura normy ISO 9001:2015, podstawowe wymagania, Problemy Jakości, 1, 25-30.

4. Egonsson, E., Bayarsaikhan, K., Ting, Ly, T. (2013). After-sales services and customer relationship marketing: a multiple case study within Swedish heavy equipment machinery industry, Kalmar: Linneus University.

5. Gębczyńska, A., Wolniak, R. (2018). Process management level in local governemnt, Philadelphia: CreativeSpace.

6. Hillson, D. (2001). Effective strategies for exploiting opportunities, Nashville: Tennessee.

7. Horodecka, A.M., Wolniak, R. (2015). Valutazione delle non conformita nell'esempio di un Azienda Italiana. In: J. Kaźmierczak (Ed.), Systemy Wspomagania Inżynierii Produkcji. Review of problems and solutions, 18-31.

8. Hoyle, D. (2009). ISO 9000. Quality systems handbook. Boston: Elsevier.

9. ISO 9001:2015. Quality management systems - Requirements.

10. Juszczak-Wiśniewska, A., Ligarski M. (2015). Weryfikacja przydatności opracowanego narzędzia badawczego do analizy problemów w systemach zarządzania jakością, Zeszyty Naukowe Politechniki Ślaskiej. Seria Organizacji i Zarządzanie, 80, 133-141.

11. Juszczak-Wiśniewska, A., Ligarski, M. (2015). Analysis of the causes the quantitative changes and trends in conferred ISO 9001 certificates in Poland Research based on the data from audits, Systemy Wspomagania w Inżynierii Produkcji, 1, 42-50.

12. Juszczak-Wiśniewska, A., Ligarski, M. (2016). Akredytacja i certyfikacja systemów zarządzania jakością w placówkach medycznych w Polsce - wyniki badań, Systemy Wspomagania w Inżynierii Produkcji, 2, 163-171.

13. Kaoru, I. (1988). What is Total Quality Control? The Japanese Way, Prentice-Hall: Englewood Cliffs.

14. Łagowski, E., Żuchowski, J. (2016). Aktualizacje normy ISO 9001 w aspekcie bieżących potrzeb gospodarczych, Problemy Jakości, 10, 15-22.

15. Ligarski, M. (2013). Problems examination in quality management system, Acta Technologica Agriculture, 4, 108-112.

16. Ligarski, M. (2014). Diagnoza systemu zarządzania jakością w polskich organizacjach, Problemy Jakości, 5, 14-22. 
17. Locher, D. (2008). Value Stream Mapping for Lean Development, New York: Taylor \& Francis.

18. Łuczak, J., Wolniak, R. (2016). Integration of quality environment and safety management systems in a foundry, Metalurgija, 4, 843-845, 2016.

19. Misztal, A. (2013). When you need validation of the process? Machines Technology Materials, 11, 53-67.

20. Mitra, A. (2016). Fundamentals of Quality Control improvement, New Jersey: Wiley \& Sons.

21. Montgomery, D.C. (2009). Introduction to statistical quality control, New York: Wiley \& Sons.

22. Natarajan, D. (20150. Reliable design of electronic equipment: an engineering guide, Bangalore: Springer.

23. Natarajan, D. (2017). ISO 9001. Quality Management Systems, Bangalore: Springer.

24. Novakova, R., Cekanova, K., Paulikova, A. (2016). Integration management system - new of requirements of ISO 9001:2015 and ISO 14001:2015 standards, Production Engineering Archives, 4, 35-40.

25. Olkiewicz, M., Wolniak, R., Grebski, E.M., Olkiewicz, A. (2019). Comparative analysis of the impact of the business incubator center on the economic sustainable development of regions in USA and Poland, Sustainability, 1, 1-22.

26. Pacana, A. (2014). Synteza i doskonalenie wdrażania systemów zarządzania jakościa zgodnych z ISO 9001 w małych i średnich organizacjach, Rzeszów: Oficyna Wydawnicza Politechniki Rzeszowskiej.

27. Pacana, A., Gazda, A., Bednárová, L. (2014). The impact of quality information on innovatory environment of the publlic administration, International Journal of Interdisciplinarity in Theory and Practice, 4, 25-26

28. Pacana, A., Ingaldi, M., Czajkowska, A. (2017). Projektowanie $i$ wdrażanie sformalizowanych systemów zarządzania, Rzeszów: Wydawnictwo Politechniki Rzeszowskiej.

29. Pacana, A., Lew, G., Kulpa, W. (2017). Rating the quality of implementation of environmental management systems. Journal of Business \& Retail Management Research, 11(2), 165-169

30. Pacana, A., Stadnicka, D. (2006). Wdrażanie i audytowanie systemów zarzadzania jakościa zgodnych z norma ISO 9001:2000, Rzeszów: Oficyna Wydawnicza Politechniki Rzeszowskiej.

31. Pacana, A., Stadnicka, D. (2017). Nowoczesne systemy zarządzania jakościa zgodne z ISO 9001:2015, Rzeszów: Wydawnictwo Politechniki Rzeszowskiej.

32. Poksińska, P., Dahlgaard, J.J., Marc, A. (2002). The state of ISO 9000 certification. A study of Swedish organizations, The TQM Magazine, 5, 297-305. 
33. Purushothama, B. (2015). Implementing ISO 9001:2015, New Delhi: Woodhead Publishing India.

34. Robbins, S., Coulter, M. (2006). Management, New York: Prentice Hall.

35. Salvendy, G. (2001). Handbook of Industrial Engineering. Technology and operations Management, New York: John Wiley \& Sons.

36. Ścierski, J. (2011). Nowelizacja normy ISO 9001, Zeszyty Naukowe Politechniki Ślaskiej. Seria Organizacji i Zarzadzanie, 59, 101-117.

37. Stamatis, D.H. (1995). Understanding ISO 9000 and implementing the basics to Quality. New York: CRC Press.

38. Sułkowski, M., Wolniak, R. (2016). Przegląd stosowanych metod oceny skuteczności i efektywności organizacji zorientowanych na ciągłe doskonalenie, Zeszyty Naukowe Politechniki Śląskiej. Seria Organizacja i Zarzadzanie, 67, 63-74.

39. Sułkowski, M., Wolniak, R. (2018). Poziom wdrożenia instrumentów zarzadzania jakościa w przedsiębiorstwach branży obróbki metali, Częstochowa: Oficyna Wydawnicza Stowarzyszenia Menedżerów Produkcji i Jakości.

40. Szczucka Lasota, B., Wolniak, R. (2018). Control plan and research supply as a tool in the process of decision making, Zeszyty Naukowe Politechniki Ślaskiej. Seria Organizacja i Zarządzanie, 115, 439-447.

41. Szkiel, A. (2016). Orientacja na klienta w wymaganiach normy ISO 9001:2015, Marketing i Zarządzanie, 3, 83-93.

42. Vogt, K. (2010). Human as an important factor in process production control, $7^{\text {th }}$ international BAAAM Baltic Conference.

43. Wolniak, R. (2011). Parametryzacja kryteriów oceny poziomu dojrzałości systemu zarządzania jakościa, Gliwice: Wydawnictwo Politechniki Śląskiej.

44. Wolniak, R. (2013). A typology of organizational cultures in terms of improvement of the quality management, Manager, 17(1), 7-21.

45. Wolniak, R. (2013). Normalizacja zarządzania jakością a wymiary kulturowe kraju, Problemy Jakości, 9, 19-25.

46. Wolniak, R. (2013). Projakościowa typologia kultur organizacyjnych, Przeglad Organizacji, 3, 13-17.

47. Wolniak, R. (2013). W kierunku ISO 9001:2015, Problemy Jakości, 2, 10-14.

48. Wolniak, R. (2014). Korzyści doskonalenia systemów zarządzania jakością opartych o wymagania normy ISO 9001:2009, Problemy Jakości, 3, 20-25.

49. Wolniak, R. (2016). Kulturowe aspekty zarządzania jakością. Etyka biznesu i zrównoważony rozwój, Interdyscyplinarne studia teoretyczno-empiryczne, 1, 109-122.

50. Wolniak, R. (2016). Metoda QFD w zarządzaniu jakościa. Teoria i praktyka, Gliwice: Wydawnictwo Politechniki Śląskiej. 
51. Wolniak, R. (2017). Analiza relacji pomiędzy wskaźnikiem innowacyjności a nasyceniem kraju certyfikatami ISO 9001, ISO 14001 oraz ISO / TS 16949. Kwartalnik Organizacja i Kierowanie, 2, 139-150.

52. Wolniak, R. (2017). Analiza wskaźników nasycenia certyfikatami ISO 9001, ISO 14001 oraz ISO/TS 16949 oraz zależności pomiędzy nimi, Zeszyty Naukowe Politechniki Ślaskiej. Seria Organizacji i Zarządzanie, 108, 421-430.

53. Wolniak, R. (2017). The Design Thinking method and its stages, Systemy Wspomagania Inżynierii Produkcji, 6, 247-255.

54. Wolniak, R. (2017). The use of constraint teory to improve organization of work, 4th International Multidisciplinary Scientific Conference on Social Sciences and Arts. SGEM 2017, 24-30 August 2017, Albena, Bulgaria. Conference proceedings. Book 1, Modern science. Vol. 5, Business and management. Sofia: STEF92 Technology, 10931100.

55. Wolniak, R. (2019). Context of the organization in ISO 9001:2015, Silesian University of Technology Scientific Papers. Organization and Management Series, 133, 121-136.

56. Wolniak, R. (2019). Downtime in the automotive industry production process - cause analysis, Quality, Innovation, Prosperity, 2, 101-118.

57. Wolniak, R. (2019). Leadership in ISO 9001:2015, Silesian University of Technology Scientific Papers. Organization and Management Series, 133, 137-150.

58. Wolniak, R. (2019). Support in ISO 9001:2015, Silesian University of Technology Scientific Papers. Organization and Management Series, 137, 247-261.

59. Wolniak, R. (2019). The level of maturity of quality management systems in Poland-results of empirical research, Sustainability, 15, 1-17.

60. Wolniak, R. (2020). Quantitative relations between the implementation of industry management systems in European Union countries, Silesian University of Technology Scientific Papers. Organization and Management Series, 142, 33-44.

61. Wolniak, R., Grebski, M.E., Skotnicka-Zasadzień, B. (2019). Comparative analysis of the level of satisfaction with the services received at the business incubators (Hazleton, PA, USA and Gliwice, Poland), Sustainability, 10, 1-22.

62. Wolniak, R., Hąbek, P. (2015). Quality management and corporate social responsibility. Systemy Wspomagania w Inżynierii Produkcji, 1, 139-149.

63. Wolniak, R., Skotnicka, B. (2011). Metody i narzędzia zarządzania jakościa - Teoria i praktyka, cz. 1, Gliwice: Wydawnictwo Naukowe Politechniki Śląskiej.

64. Wolniak, R., Skotnicka-Zasadzień, B. (2008). Wybrane metody badania satysfakcji klienta i oceny dostawców w organizacjach, Gliwice: Wydawnictwo Politechniki Śląskiej.

65. Wolniak, R., Skotnicka-Zasadzień, B. (2010). Zarządzanie jakościa dla inżynierów, Gliwice: Wydawnictwo Politechniki Śląskiej.

66. Wolniak, R., Skotnicka-Zasadzień, B. (2014). The use of value stream mapping to introduction of organizational innovation in industry, Metalurgija, 53(4), 709-713. 
67. Wolniak, R., Skotnicka-Zasadzień, B., Zasadzień, M. (2019). Problems of the functioning of e-administration in the Silesian region of Poland from the perspective of a person with disabilities, Transylvanian Review of Public Administration, 57E, 137-155.

68. Wolniak, R., Sułkowski, M. (2015). Motywy wdrażanie certyfikowanych Systemów Zarządzania Jakością. Problemy Jakości, 9, 4-9.

69. Wolniak, R., Sułkowski, M. (2015). Rozpowszechnienie stosowania Systemów Zarządzania Jakością w Europie na świecie - lata 2010-2012, Problemy Jakości, 5, 29-34.

70. Wolniak, R., Sułkowski, M. (2016). The reasons for the implementation of quality management systems in organizations, Zeszyty Naukowe Politechniki Śląskiej. Seria Organizacji i Zarządzanie, 92, 443-455.

71. Ząbek, J.: (2016). ISO 9001:2015. Wybrane problemy zarządzania z perspektywy nowej normy, Ekonomika i Organizacja Przedsiębiorstwa, 2, 14-25.

72. Żemigała M. (2017). Tendencje w badaniach nad normą ISO 9001. Problemy Jakości, 3, 2-9. 